Научная статья

УдК 008

DOI https://doi.org/10.24866/VVSU/2073-3984/2021-3/166-182

Т.В. Метляева ${ }^{1}$

И.Е. Перетолчина

Владивостокский государственный университет экономики и сервиса.

Владивосток. Россия

\title{
Особенности развития событийных мероприятий в контексте туристской привлекательности территории
}

\begin{abstract}
В данной статье рассматриваются особенности развития событийных мероприятий в контексте туристской привлекательности территории в современных условиях. Анализируются подходы к определению понятий «имидж территории», «событийный туризм», «событийные мероприятия», «туристская привлекательность». Выявляются подходы к формированию туристской привлекательности города. Сравниваются такие сходные понятия, как «стереотип», «мнение», «представление» и "образ», и прослеживаются связь и влияние событийных мероприятий на туристскую привлекательность территории. Рассматриваются особенности и перспективы развития модной индустрии в России и Приморском крае. Выявляется востребованность событийного туризма на современном этапе развития индустрии гостеприимства. Демонстрируется возможность использования fashionмероприятий для совершенствования имиджа города и позиционирования его как привлекательного места для туризма. В статье представлены результаты исследования, посвященного изучению часто посещаемых имиджевых объектов города Владивостока туристами и анализу востребованности деятельности приморских дизайнеров жителями Владивостока. Обоснована возможность продвижения Владивостока как туристской дестинации через мероприятия модной индустрии города. Предмет исследования - событийные мероприятия в контексте туристской привлекательности территории. Цель - исследовать особенности развития событийных мероприятий в контексте туристской привлекательности города Владивостока. Исследовательский интерес обусловлен рассмотрением влияния событийных мероприятий, связанных с модной индустрией, на туристскую привлекательность территории. Новизна работы заключается в отсутствии достаточ-
\end{abstract}

\footnotetext{
${ }^{1}$ Метляева Татьяна Викторовна - канд. культурологии, доцент кафедры дизайна и технологий; e-mail: Metlaevatv@ mail.ru

2 Перетолчина Ирина Евгеньевна - студент кафедры дизайна и технологий; e-mail: irinaperetol@gmail.com

166
} 
Т.В. Метляева, И.Е. Перетолчина. Особенности развития событийных мероприятий...

ного количества научных исследований, посвященных влиянию модной индустрии на туристскую привлекательность территории. В работе применялся адаптационный подход, структурно-функциональный и социологический методы в форме анкетирования. Большое внимание авторы уделяют анализу проведенного опроса и обоснованию выбора мероприятий для увеличения туристской привлекательности города Владивостока посредством модных событий города.

Ключевые слова и словосочетания: туристская привлекательность, имидж территории, событийный туризм, модная индустрия.

\section{T.V. Metlyaeva}

\section{I.E. Peretolchina}

Vladivostok State University of Economics and Service Vladivostok. Russia

\section{Features of the development of events in the context of the tourist attractiveness of the territory}

This article examines the features of the development of event activities in the context of the tourist attractiveness of the territory in modern conditions. The approaches to the definition of concepts on the research topic "image of the territory", "event tourism", "event events", "tourist attraction" are analyzed. The approaches to the formation of the tourist attractiveness of the city are revealed. It compares similar concepts such as "stereotype", "opinion", "performance" and "image" and traces the connection and influence of event events on its tourist attractiveness. The features and prospects for the development of the fashion industry in Russia and in the Primorsky Territory are considered. The demand for event tourism at the present stage of the development of the hospitality industry is revealed. The possibility of using fashion events to improve the image of the city and position it as an attractive place for tourism is demonstrated. The article presents the results of a study devoted to the study of frequently visited image objects in the city of Vladivostok by tourists and an analysis of the demand for the activities of coastal designers by residents of Vladivostok. The possibility of promoting Vladivostok as a tourist destination through the events of the city's fashion industry has been substantiated. Subject of research: event events in the context of the tourist attractiveness of the territory. Purpose: to study the features of the development of event events in the context of the tourist attractiveness of the city of Vladivostok. In this article, our research interest is related to the consideration of the impact of events related to the fashion industry on the tourist attractiveness of the territory. The novelty of the work lies in the lack of a sufficient number of scientific studies devoted to the influence of the fashion industry on the tourist attraction of the territory. An adaptive approach, a structural-functional and sociological method in the form of a questionnaire was used in the work. In this connection, the authors pay great attention to the analysis of the survey and justification of the choice of activities to increase the tourist attractiveness of the city of Vladivostok through the fashionable events of the city.

Keywords: tourist attraction, image of the territory, event tourism, fashion industry.

\section{Введение}

В основной части исследования для достижения поставленной цели - исследовать особенности развития событийных мероприятий в контексте туристской 
привлекательности города Владивостока» - необходимо было решить следующие задачи:

- рассмотреть подходы к определению понятий «туристская привлекательность», «событийный туризм», «имидж территории»;

- выявить ассоциативное восприятие города Владивостока, некоторые предпочтения современных туристов, уровень знакомства местных жителей с событийными fashion-мероприятиями города;

- проанализировать возможные варианты продвижения города Владивостока как привлекательной туристской дестинации.

В современном мире туризм становится важной частью жизни множества людей. Вместе с этим туризм является стабильным и развивающимся сектором экономики XXI века и одной из крупнейших отраслей торговли услугами. Доля туризма занимает большую часть в ВВП разных стран мира.

В условиях рыночной экономики муниципальные образования сталкиваются с конкуренцией в процессе привлечения на территорию туристов, инвесторов и граждан на постоянное место жительства. Для решения данной проблемы необходимо постоянно работать над туристской привлекательностью территории. Высокий уровень туристской привлекательности позволяет успешно привлекать на территорию потребителей и определять перспективные направления развития муниципального образования.

\section{Основная часть}

В современных научных исследованиях представлено множество определений понятия «туристская привлекательность». Это обусловлено тем фактом, что данное понятие так и не получило универсальной трактовки. Как следствие, возможны лишь разнообразные описания данной области знаний, в зависимости от конкретных целей исследования.

Можно проследить различие в понимании сущности туристской привлекательности в работах таких авторов, как В.В. Славин, С. П. Кузик, Е. О. Ушакова и С. А. Вдовин и др. Многие ученые в своих работах опираются на понимание привлекательности как свойства объекта, который привлекает набором определенных качественных характеристик, вызывает восхищение и чувство эстетического удовольствия [6]. Интересной представляется идея С. К. Волкова, который вкладывает в термин «туристская привлекательность» наличие комплекса вербальных и визуальных характеристик, психоэмоциональных реакций, формирующих отношение туристов к той или иной местности [3]. Косвенным подтверждением этого вывода являются результаты многих исследований, указывающих на зависимость роста туристской привлекательности местности от наличия «фотографируемых мест» - экзотических и уникальных объектов, подходящих для показа туристам (как исторические здания, так и природные ландшафты), вызывающих особое психоэмоциональное состояние, эстетическое удовлетворение от путешествия [11; 12].

В трудах А. Пун рассматривается необходимость современных путешественников в создании положительных впечатлений посредством целостного, эмоционально насыщенного опыта пребывания [13]. Таким образом, туристская 168 
привлекательность местности для туристов напрямую связана с «задействованием» всех органов чувств, которые доставляют туристу новые впечатления и эмоции и пополняют его опыт путешествий. В трудах А. Пун современные путешественники характеризуются как «новые туристы», которые в основном имеют достаточный опыт в сфере туристических путешествий, эмоционально насыщены и поэтому более требовательны к необходимому набору впечатлений. Исследователь приходит к выводу, что «новый турист» - это не зритель, а участник действия. Становится заметнее необходимость интеграции социального ресурса - местного населения, которое формирует социальные линии потребления туристского продукта и обеспечивает высокий уровень участия туристов в местной культуре и событийных мероприятиях.

В современных условиях наблюдается желание туристов глубже включаться в местную культуру и события, возрастает необходимость использовать социальный ресурс - местных жителей, которые могут обеспечить нужный уровень вовлеченности. Так, для увеличения туристской привлекательности территории целесообразно делать ставку на событийный туризм - организацию мероприятий, позволяющих привлечь дополнительный поток туристов и позиционирующих территорию как привлекательный объект для приезжающих по уже определенной причине - посетить мероприятие.

Содержание понятия «событийный туризм» раскрыли в своих работах А.А. Глушко, Ю.А. Киреева, И.В. Зорин, В.А. Квартальнов, А.М. Сазыкин и др.

По мнению ряда авторов, дестинация событийного туризма включает в себя следующие компоненты: событие (event) как основа, инфраструктура, реклама и продвижение, информационный туристский центр, достопримечательности, сопутствующие развлечения и доступность, которые, в свою очередь, находятся в постоянном взаимодействии с факторами внешней среды.

Автор книги «Специальные виды туризма» А. В. Бабкин выделяет в событийном туризме следующие тематические виды:

- национальные фестивали и праздники;

- театрализованные шоу;

- фестивали кино и театра;

- гастрономические фестивали;

- фестивали и выставки цветов;

- модные показы;

- аукционы;

- фестивали музыки и музыкальные конкурсы;

- спортивные события [1].

Главная особенность событийного туризма заключается во множестве ярких неповторимых моментов. Следует отметить, что событийный туризм является уникальным видом туризма, так как неисчерпаем по содержанию. О. К. Слинкова и Ю. П. Грицак полагают, что в недалеком будущем число участников событийных туров превысит число участников экскурсионных туров [5;9]. 
Одним из важных аспектов туристической привлекательности является имиджевая составляющая местности. В настоящее время у ученых нет единого мнения относительно понятия «имидж территории». Говоря об имидже территории, Д.П. Гавра имеет в виду совокупность представлений о стране (городе, регионе), основанных на собственном опыте, легендах и слухах, которые в конечном итоге создают определенный образ [4].

Существует несколько подходов к определению основных составляющих имиджа территории. В контексте данного исследования нам интересна точка зрения И.С. и С.Г. Важениных, определяющих имидж территории через его составляющие: природно-климатические, исторические, этнографические, социально-экономические, политические, морально-психологические и другие. Все характеристики и ресурсы территории разделены авторами на три блока:

- природные, демографические, исторические, социальные и культурные особенности и ресурсы;

- экономические особенности и ресурсы;

- организационно-правовые, информационные особенности и ресурсы [7].

Одним из способов формирования туристской привлекательности можно считать позиционирование города через модную индустрию. В современном мире модная индустрия - вторая индустрия потребления после продуктов питания. Ежегодно по всему миру продается более 80 миллиардов предметов одежды. Ежегодный рост рынка индустрии моды составляет 10-15\%. По данным Fashion United.com, общий оборот этого сектора экономики составляет более 3 трлн долларов США. На индустрию моды приходится $2 \%$ мирового ВВП. Несмотря на развитие этого направления в мире, многие экономисты отмечают, что российская модная индустрия и все, что с ней связано, последние годы находились в плачевном состоянии. С 2013 по 2017 год продажи одежды в России выросли всего на $1,3 \%$, при этом в продаже одежды в России преобладает импортная продукция, доля российских производителей на рынке текстильной продукции не превышает $40 \%$ от его объема [10].

Недавний экономический кризис способствовал росту интереса населения к отечественным товарам и благоприятно сказался на развитии легкой промышленности. Издержки производства в стране снизились, и отечественный товар стал конкурентоспособным. У российских компаний, дизайнеров и ритейлеров появился шанс укрепить свои позиции на рынке.

Отдельно следует отметить, что в результате ослабления рубля ввоз многих товаров (преимущественно низких и средних ценовых категорий) из-за рубежа стал невыгодным или невозможным для участников рынка ввиду санкций и пограничных запретов. При этом себестоимость продукции в стране упала до уровня азиатских фабрик [8]. Популярность российских товаров также стала расти. Оказалось, что местный рынок легкой промышленности для Российской Федерации не был полностью потерян. Кроме того, начал увеличиваться экспорт, росту которого помимо девальвации способствовала профильная государственная политика. Введенные импортные ограничения ослабили позиции иностранных игроков и вселили оптимизм в инвесторов, 
Т.В. Метляева, И.Е. Перетолчина. Особенности развития событийных мероприятий...

которые начали более активно вкладывать средства в модернизацию и создание новых местных производств. Правительственные субсидии предприятиям легкой промышленности, включая кредиты, также сыграли свою роль. По мнению экспертов, результат сначала привел к увеличению производства тканей, одежды и обуви, а затем к повышению качества продукции.

По мнению экспертов, за последние годы значительно повысился и уровень дизайна изделий, несмотря на то, что швейным фабрикам и дизайнерам зачастую сложно найти точки соприкосновения. Иностранных предпринимателей интересует дешевый и качественный текстиль для перепродажи. Здесь следует подчеркнуть, что более 50\% экспорта оценивается Торгово-промышленной палатой Российской Федерации как готовая продукция [8].

К последствиям недавнего экономического спада можно отнести трансформацию потребительского спроса. Согласно исследованию Price waterhouse Coopers, в Российской Федерации начали формироваться своего рода покупательская дисциплина и культура потребления. Современный потребитель сегодня иначе относится к покупке товара, становится более требовательным и внимательным к цене и качеству товаров. В результате происходит ориентация на недорогие бренды, которые по-прежнему предлагают модели одежды и обуви на достаточно высоком уровне для своего сегмента. В таких условиях известность бренда постепенно теряет значение. Таким образом, внимание покупателей сосредоточивается на достаточно качественных моделях одежды и обуви, интерес потребителей к одежде из масс-маркета снижается, а спрос на местных дизайнеров, предлагающих товары лучшего соотношения «цена-качество», растет.

На фоне изменения моделей потребления и снижения себестоимости продукции в России, по данным Financial Consulting Group, наблюдаются рост количества местных участников среднего и малого бизнеса в индустрии моды, развитие малых брендов на базе российских швейных фабрик. Как уже было сказано, интерес к одежде и обуви российского производства начал расти. Так, появляется возможность привлечения локальных дизайнеров к развитию модного туризма в регионе: популяризация недель моды, проведение уникальных модных показов, открытие новых бутиков и шоурумов.

\section{Эмпирическое исследование}

Эмпирическое исследование проводилось с целью анализа влияния fashionмероприятий на туристскую привлекательность территории. В основе исследования лежит оценка подготовки и проведения премиум-показа «Путешествие во Владивосток» и «Прогулки по Владивостоку» (фотографии с показа «Путешествие во Владивосток» представлены на рис. 1a, б, с показа «Прогулки по Владивостоку» на рис. 2а, б). 
Территория новых возможностей. Вестник ВГУЭС. 2021. № 3

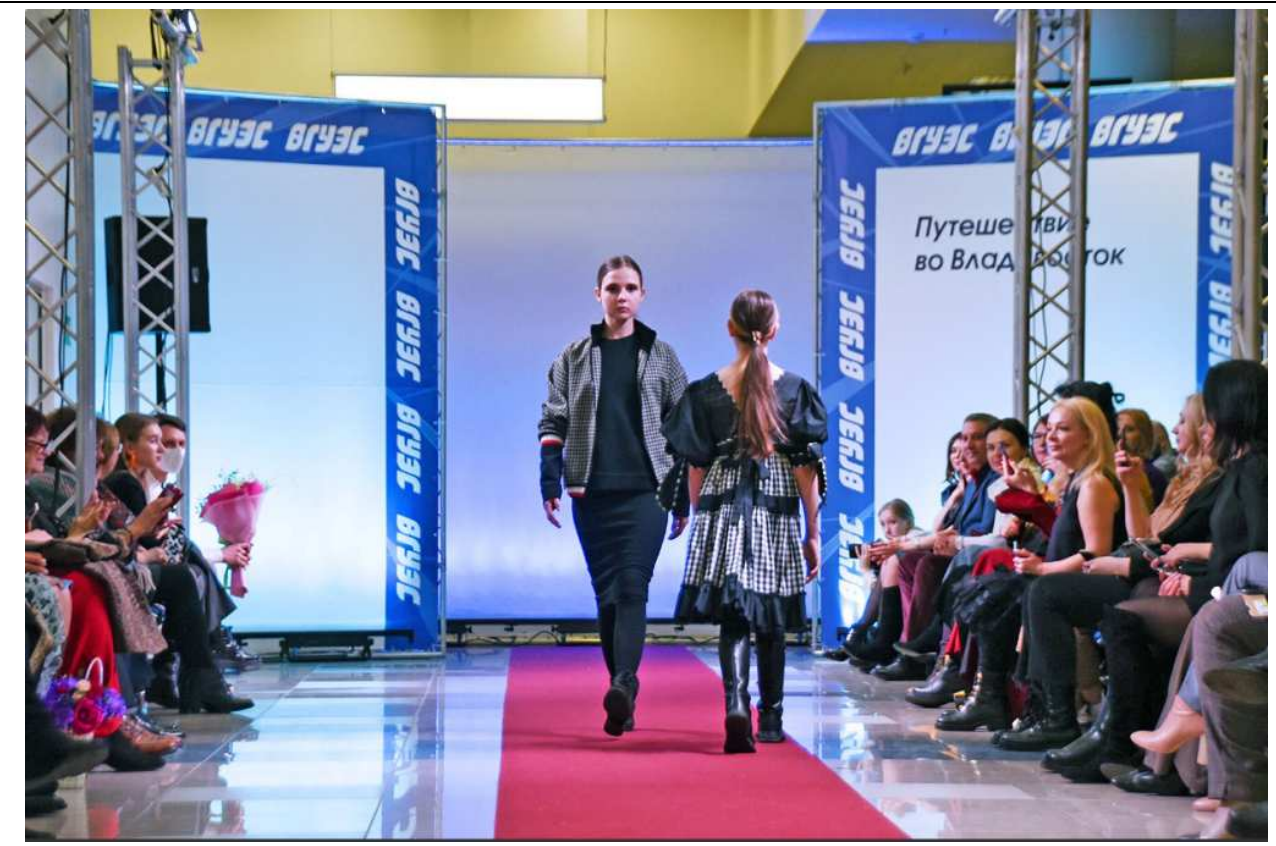

a

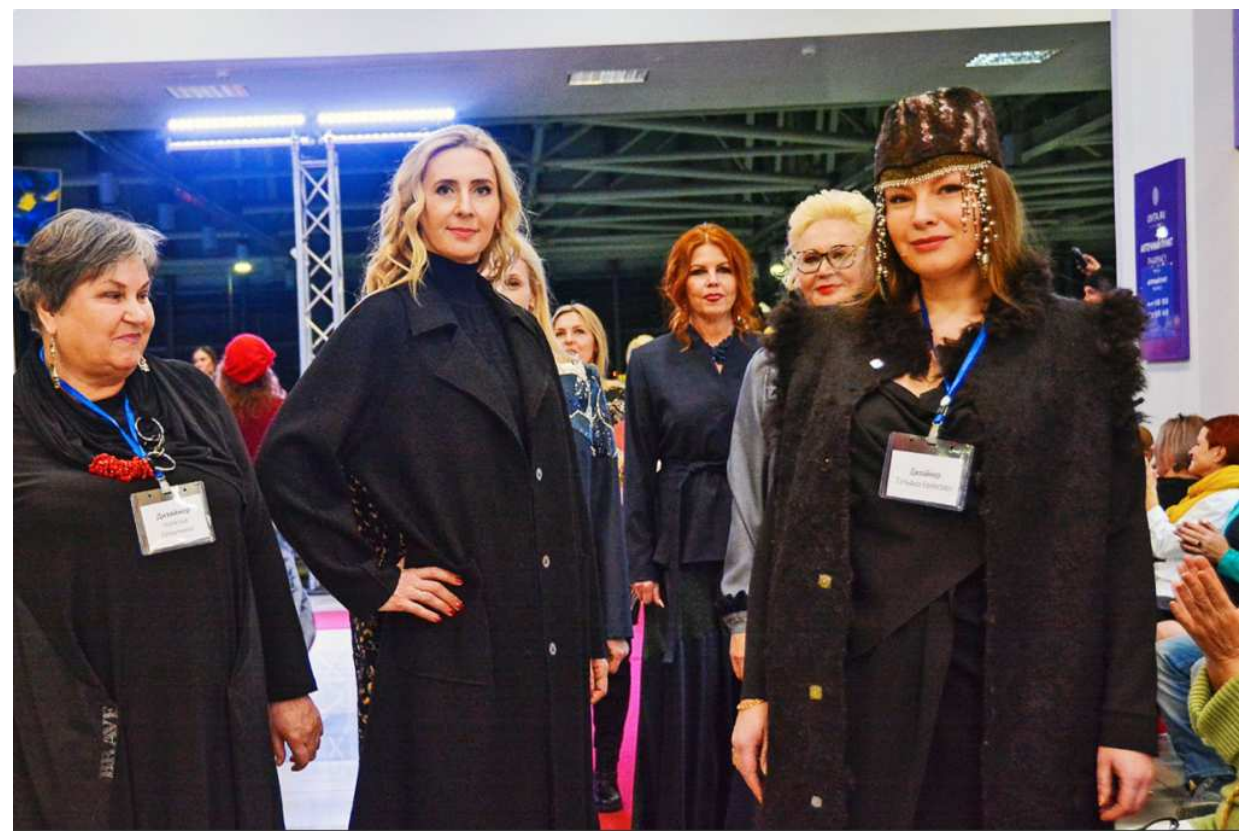

6

Рис. 1. Фотографии с показа «Путешествие во Владивосток» 
Т.В. Метляева, И.Е. Перетолчина. Особенности развития событийных мероприятий...

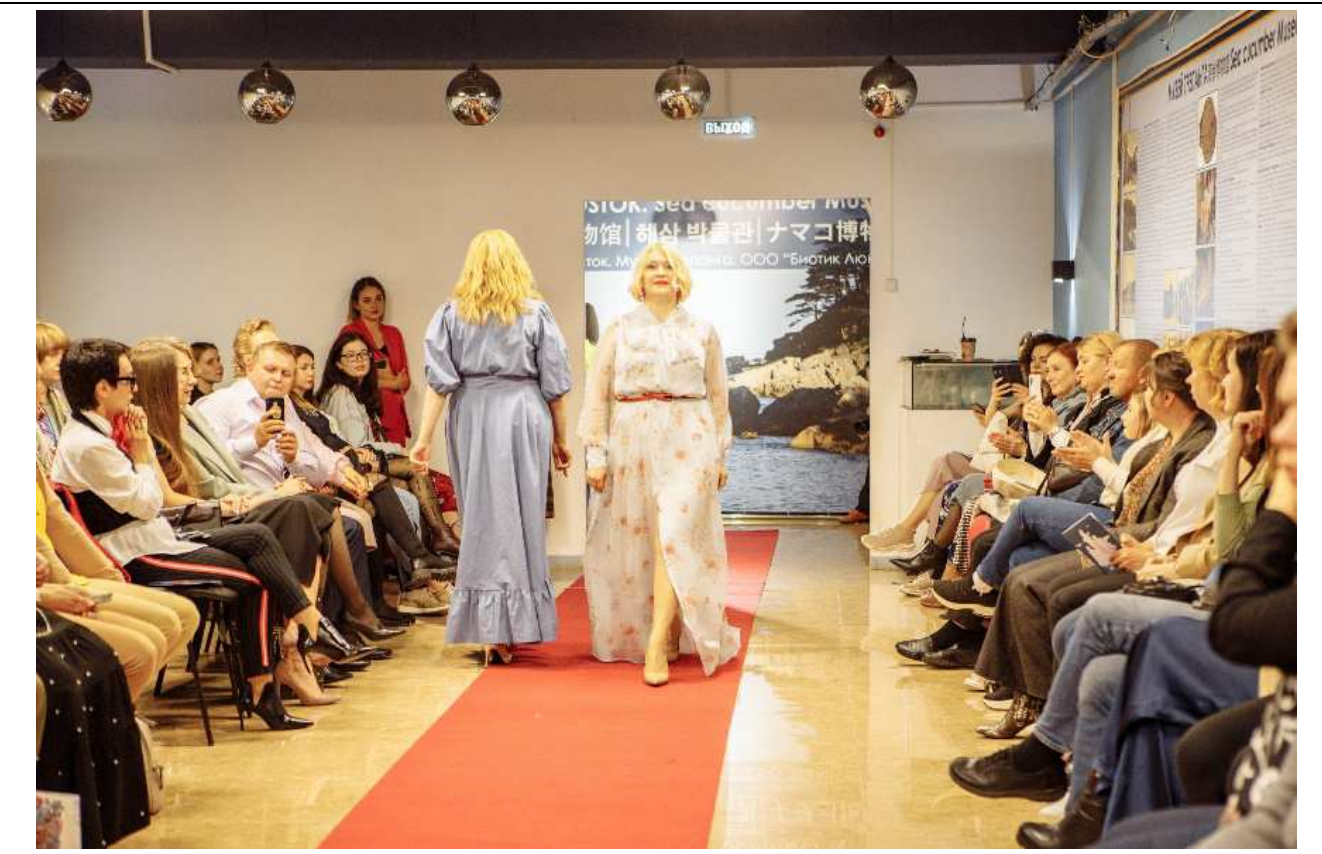

a

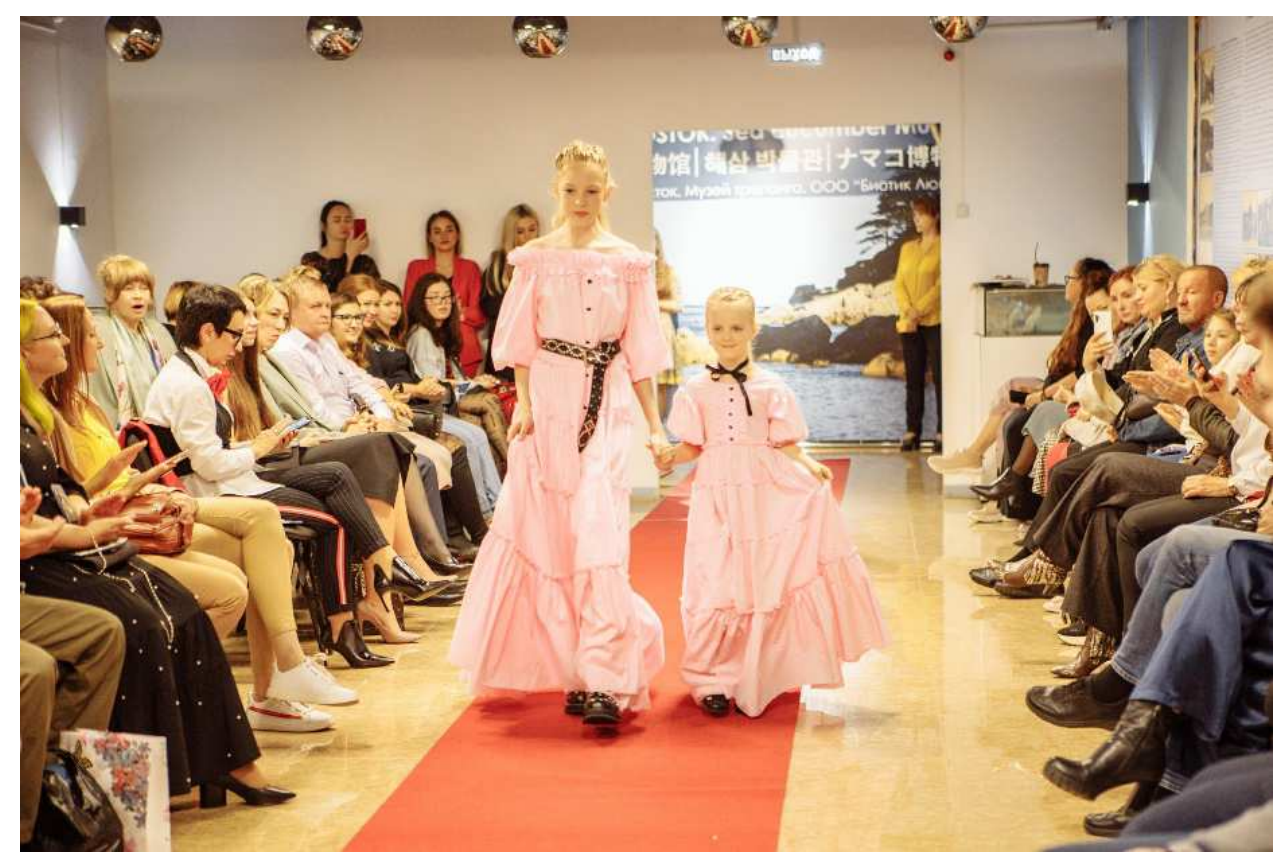

6

Рис. 2. Фотографии с показа «Прогулки по Владивостоку» 
Исследование проводилось в два этапа: 1) анализ ассоциативного восприятия города Владивостока и анализ востребованности деятельности приморских дизайнеров посредством анкетирования; 2) разработка рекомендаций для проведения событийных мероприятий, связанных с модной индустрией и развивающих туристскую привлекательность города.

С целью анализа восприятия города российскими туристами была разработана анкета. Результаты анкетирования представлены ниже.

Рассмотрев цели путешествий опрошенных для изучения востребованности видов туризма у жителей России, стало очевидно, что достаточное количество респондентов (31\%) путешествуют с целью посещения определенных мероприятий. Это говорит об актуальности событийного туризма. Результаты представлены на рис. 3.

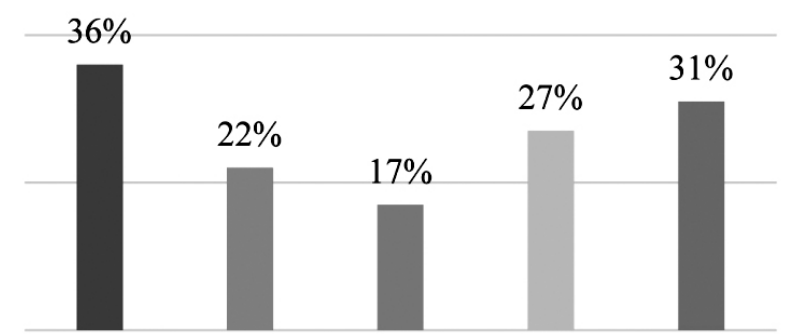

- Знакомство с достопримечательностями района и его культурой (36\%)

п Отдых в местах дикой природы, посещение природных достопримечательностей $(22 \%)$

- Спортивно-равзлекательный отдых (17\%)

—накомство с кухней региона (27\%)

Шосещение определенного мероприятия (31\%)

Рис. 3. Цели путешествий

Среди 414 опрошенных 59\% респондентов считают Владивосток интересным местом для путешествия. Результаты отражены на рис. 4.

Анализируя ассоциативное восприятие имиджа г. Владивостока со значимой фигурой, можно отметить, что $48 \%$ опрошенных ассоциируют город с Ильей Лагутенко, 29\% с Лоттой Волковой, известным стилистом из Владивостока (рис. 5). Вторая ассоциация доказывает ассоциацию города с модной средой. Результаты опроса представлены на рис. 4, 5. 


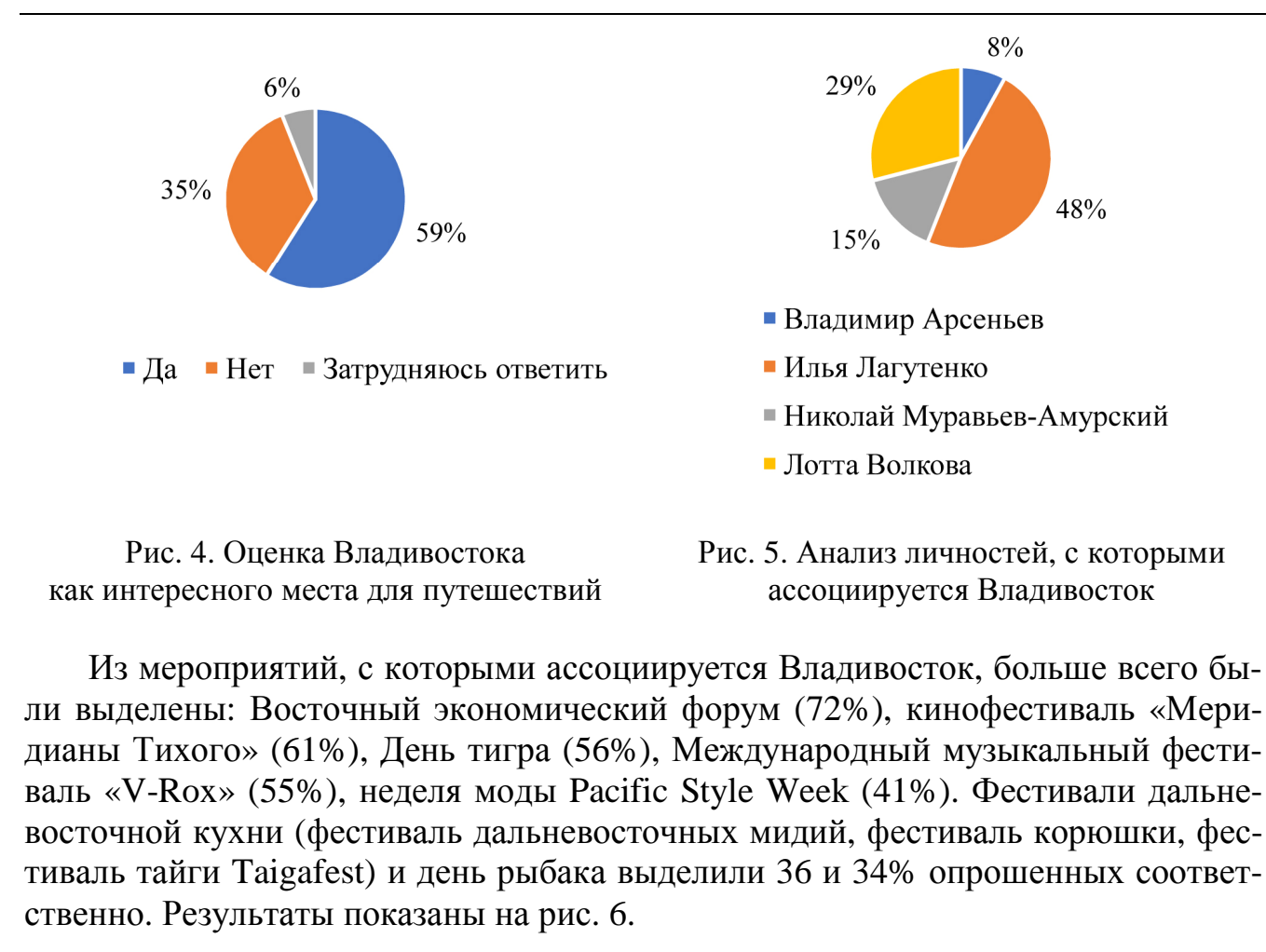

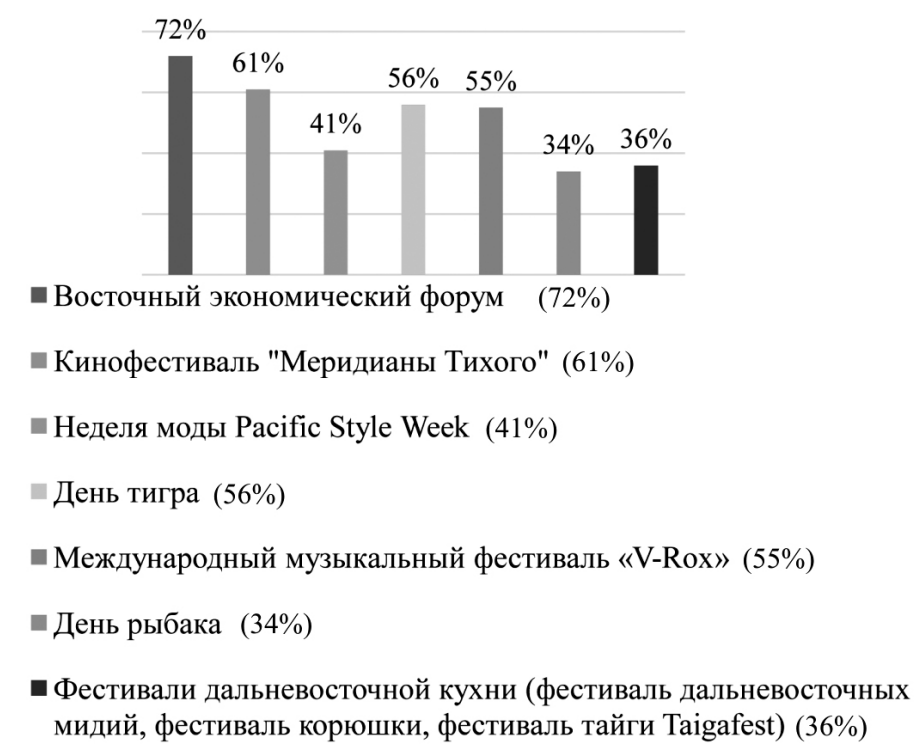

Рис. 6. Мероприятия, с которыми ассоциируется Владивосток

Анализ мнения жителей России по поводу позиционирования Владивостока показал, что 66\% опрошенных считают, что нужно делать упор на пляжный 
туризм, 49\% выбрали экологический туризм, $41 \%$ - событийный. Результаты опроса представлены на рис. 7.

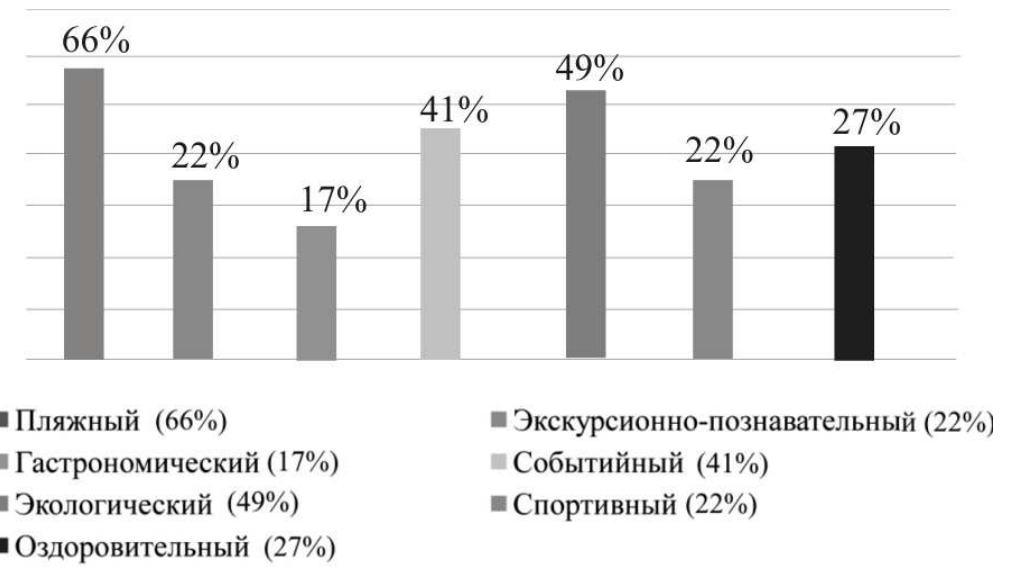

Рис. 7. Варианты для позиционирования Владивостока

Большинство респондентов (78\%) считают Владивосток модной столицей Дальнего Востока. Это позволяет сделать вывод о целесообразности привлечения в город туристов посредством проведения модных мероприятий (модные показы, недели моды, дизайнерские выставки). Результаты опроса представлены на рис. 8.

Также было проведено исследование, связанное с отношением людей к fashion-среде и уровнем знакомства с модной индустрией во Владивостоке.

Больше половины респондентов (57\%) считают, что fashion-индустрия достаточно актуальна для обсуждения и востребована в современном обществе, $31 \%$ оценивают актуальность и востребованность данной сферы очень высоко, только $12 \%$ респондентов считают fashion-индустрию вовсе не актуальной и невостребованной. Результаты опроса представлены на рис. 9.

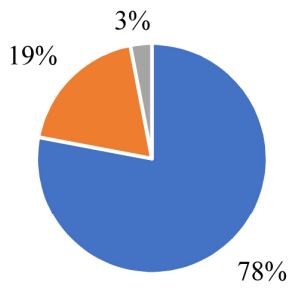

- Да " Нет - Затрудняюсь ответить

Рис. 8. Анализ оценки утверждения «Владивосток - модная столица Дальнего Востока»

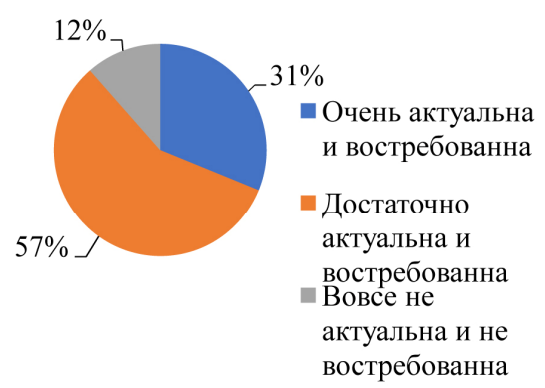

Рис. 9. Оценка актуальности и востребованности fashion-индустрии для обсуждения в современном обществе 
В результате оценки статистики осведомленности респондентов о мероприятиях, посвященных моде, выяснилось, что $58 \%$ опрошенных знакомы с премиум-показом «Путешествие во Владивосток», позиционирующим город через модную индустрию, представленную местными дизайнерами. $23 \%$ знакомы с «Московским долголетием», $10 \%$ с неделями моды в различных городах. Результаты опроса представлены на рис. 10.

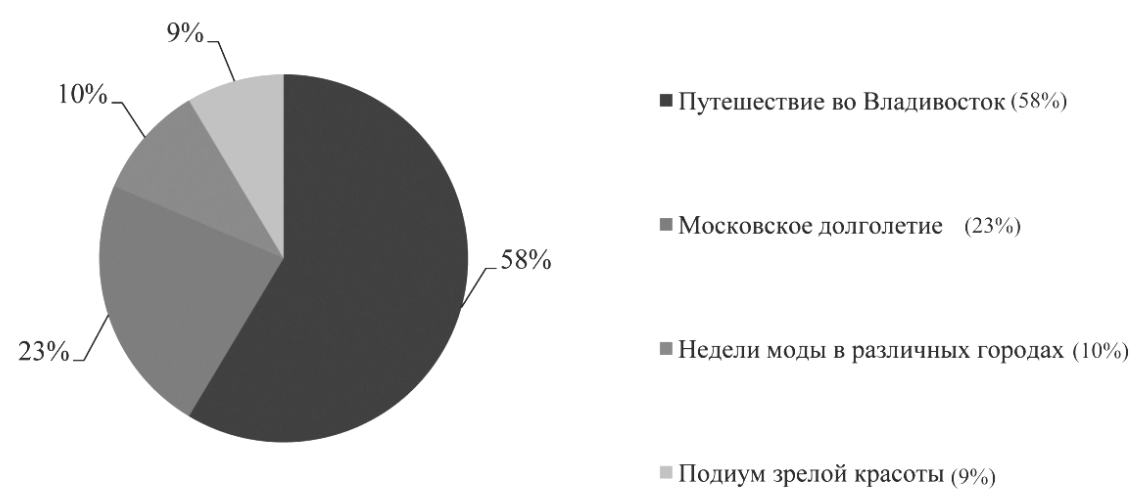

Рис. 10. Статистика осведомленности респондентов о мероприятиях, посвященных моде

Опираясь на результаты предыдущего вопроса, мы оценили количество заинтересованных респондентов, которым удалось посетить премиум-показ «Путешествие во Владивосток». Анектирование показало, что $65 \%$ респонденов не посещали данное мероприятие. 27\% посетили показ и положительно оценили впечатление от него. Результаты отражены на рис. 11.

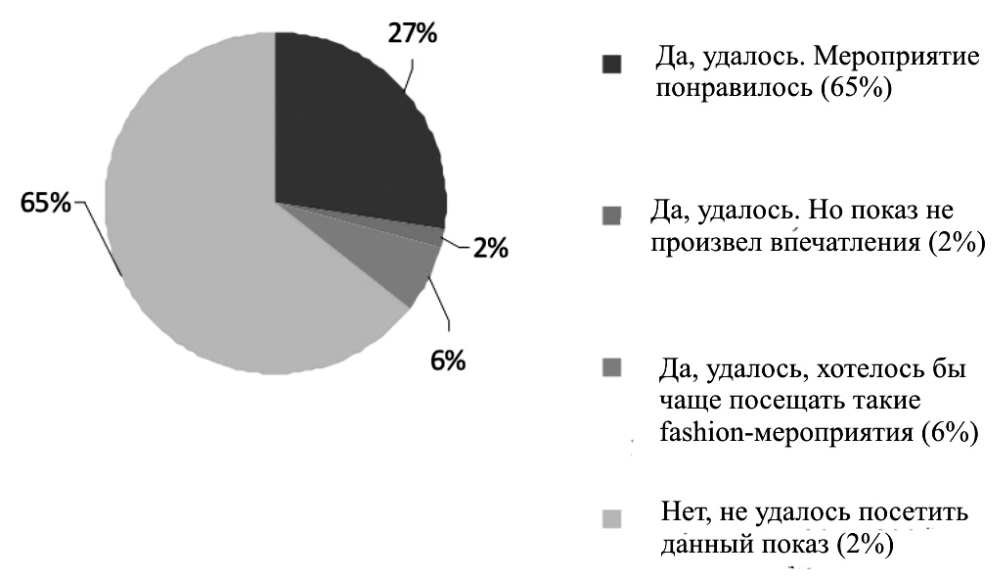

Рис. 11. Оценка посещаемости респондентами премиум-показа «Путешествие во Владивосток» 
Для анализа востребованности деятельности приморских дизайнеров жителями Владивостока был проведен опрос, в котором приняли участие 133 pecпондента из Владивостока. Были получены следующие результаты: из 133 респондентов 62\% знакомы с брендом SUCCUB. На вопрос о знакомстве с брендом Akulina Kid`s Outfit положительно ответили 58\% респондентов. По результатам анкетирования 57\% респондентов оказались знакомы с работами Милы Коба владелицы одноименного бренда. Положительный ответ на вопрос о знакомстве с брендом Goranskaya дали 54\% респондентов. Из 133 опрошенных респондентов 51\% знаком с брендом LOPKHAN дизайнера Юлии Воротниковой. $32 \%$ респондентов знакомы с работами Елены Фадеевой. На вопрос о знакомстве с брендом Luna wear Kids положительно ответили $28 \%$ респондентов. По результатам анкетирования 26\% респондентов знакомы с одеждой бренда 3 Angel. 22\% респондентов дали положительный ответ на вопрос о знакомстве с брендом Даны Заниной By Dans. По результатам анкетирования 15\% респондентов знакомы с уникальными войлочными изделиями, созданными дизайнером Натальей Лопаткиной. Результаты анкетирования отражены на рис. 12.

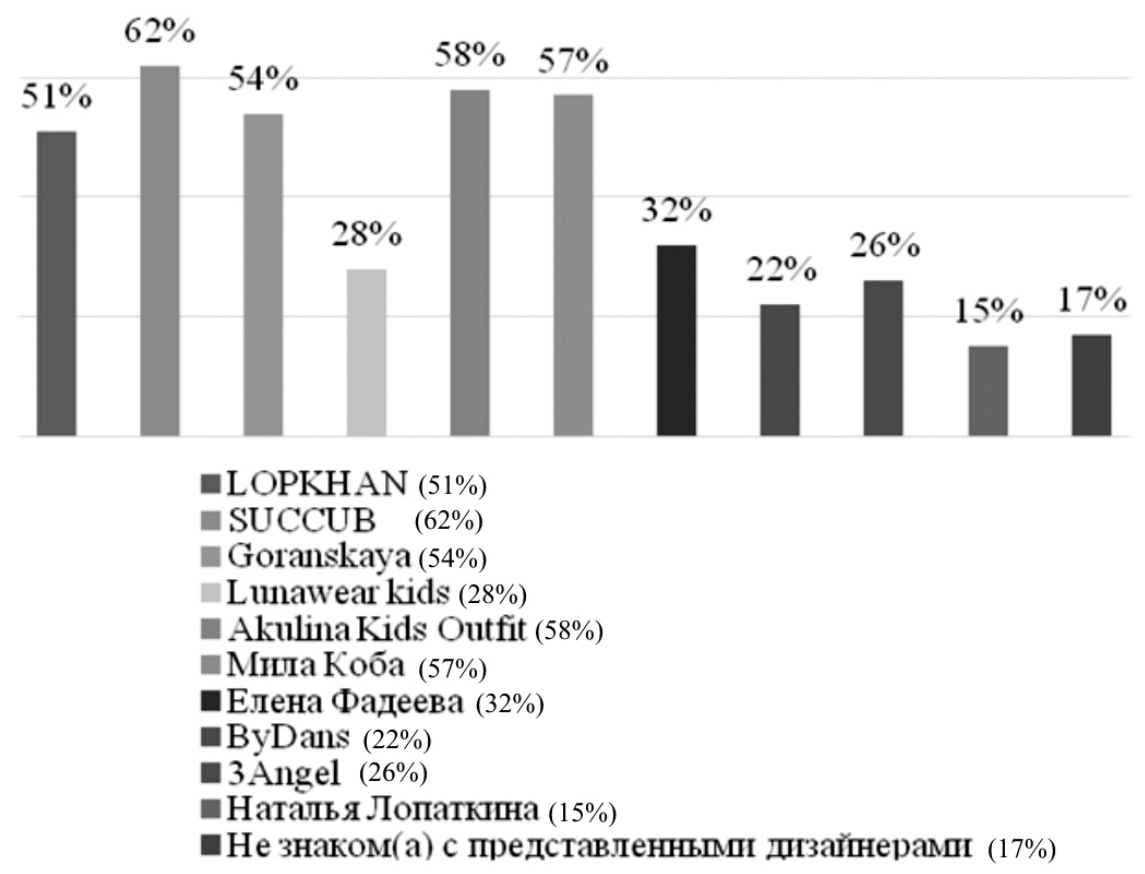

Рис. 12. Оценка известности местных дизайнеров жителями Владивостока

При анализе востребованности показов владивостокских дизайнеров 58\% респондентов отметили, что посещают показы бренда SUCCUB, 23\% выбрали показы Ирины Акулиной, 10\% анкетируемых посещают показы бренда LOPKHAN, 9\% - показы Милы Коба. Результаты представлены на рис. 13. 
Т.В. Метляева, И.Е. Перетолчина. Особенности развития событийных мероприятий...

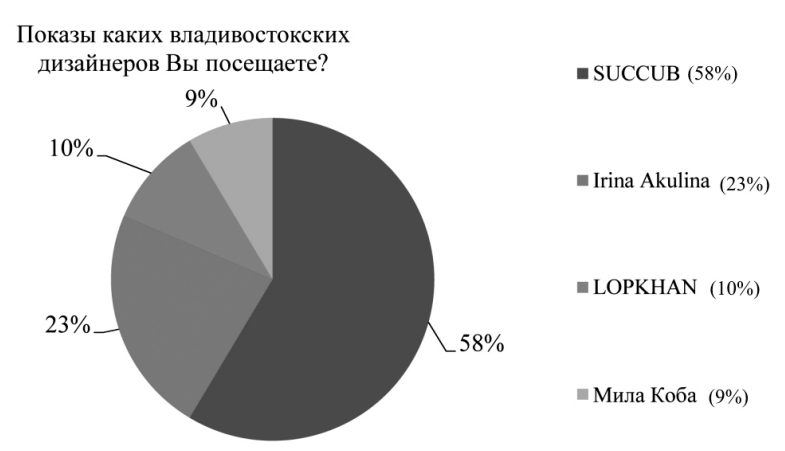

Рис. 13. Оценка посещаемости респондентами показов владивостокских дизайнеров

Таким образом, нами была выявлена достаточно высокая осведомленность жителей Владивостока в модной сфере. Большой процент опрошенных считают fashion-индустрию актуальной для обсуждения и востребованной в современном обществе, знакомы с модной сценой Владивостока, посещают показы. Большинство опрошенных посещали или слышали о премиум-показе «Путешествие во Владивосток», позиционирующем имиджевые объекты города (Спортивная набережная, квартал «Миллионка», приморская сцена Мариинского театра, приморский океанариум, фуникулер, Приморская государственная картинная галерея, владивостокский ГУМ и др.) в интеграции с местными дизайнерами.

Многие эксперты русской моды считают Приморье самым перспективным регионом модной индустрии в России. Директор магазина Zara во Владивостоке Анна Покунова называет Владивосток «третьей модной столицей России». По ее мнению, дальневосточная столица по меркам российской fashion-индустрии находится на одном уровне с Москвой и Санкт-Петербургом. Для руководителей бренда Zara, которые прилетали во Владивосток, приморская столица показалась невероятным миксом Европы и Азии [2].

Важнейшим элементом модной жизни как Владивостока, так и всего Дальнего Востока является Неделя моды и стиля Pacific Style Week - квинтэссенция модной жизни города и важное мероприятие для дизайнеров местного и международного уровней.

Исходя из исследования мы выяснили о возможности позиционирования Владивостока как модной столицы Дальнего Востока. Для этого необходимо разработать актуальные предложения (помимо проведения показа «Путешествие во Владивосток» и «Прогулки по Владивостоку») по позиционированию в этом направлении:

Во-первых, проведение модных перфомансов в рамках уже существующих городских фестивалей и праздников: гастрономических (фестиваль дальневосточных мидий, фестиваль краба «Держи краба», фестиваль тайги «Taigafest»), культурных (кинофестиваль «Меридианы Тихого», День молодежи, День города, День тигра), спортивных (экстрим-фестиваль «Мосты»). Востребованность модных перфомансов доказывается наличием площадок, проводивших подобные мероприятия: «Фэшн шоу» команды «Фэшн Юродивый» в музее «Артэ- 
таж», модные перфомансы команды Rare Set, сюрреалистичные модные показы в ЦСИ «Заря».

Во-вторых, проведение модных показов на оригинальных площадках, отражающих эклектичность Владивостока: морские порты, авторазборки с японскими машинами, дикие пляжи, показы на территории рассматриваемых в работе имиджевых объектов (например, маяк на Токаревской кошке, квартал «Миллионка», Приморская государственная картинная галерея, Ботанический сад). Объединение имиджевых туристических мест и модных показов благоприятно поспособствует позиционированию Владивостока как модной столицы Дальнего Востока.

\section{Заключение}

В результате исследования было выявлено, что мероприятия событийного туризма значительно влияют на туристскую привлекательность территории и приобретают большую популярность у современных туристов. В период их проведения активизируется деятельность всех объектов туристской индустрии. Как следствие, можно прийти к выводу, что у г. Владивостока существует потенциал позиционирования как модной столицы Дальнего Востока посредством событийных мероприятий.

В результате исследования рассмотрены такие понятия, как «туристская привлекательность», «событийный туризм», «имидж территории», а также определены направления позиционирования и территориального имиджмейкинга, благодаря которым в перспективе можно создать позитивный имидж территории, способный привлечь в регион новых туристов и граждан на постоянное место жительства.

Результаты проведенного эмпирического исследования свидетельствуют о заинтересованности жителей России в событийном туризме. Также доказаны актуальность и востребованность fashion-среды в жизни владивостокцев, знакомых с локальными модными дизайнерами и посещающих модные показы, в том числе «Путешествие во Владивосток» - событийное мероприятие, позиционирующее город через местную модную индустрию.

Подводя итог рассмотренным выше положениям и результатам проведенного исследования, необходимо отметить, что разработанные и внедренные мероприятия доказывают возможность представлять город Владивосток посредством мероприятий, взаимодействующих с локальной fashion-средой. Полученные результаты требуют дальнейших исследований, доказывающих и демонстрирующих значение уникального позиционирования территории для увеличения ее туристской привлекательности.

1. Бабкин А. В. Специальные виды туризма // Вопросы науки и практики: материалы III международной научно-практической конференции. - Москва, 2018. - С. 262-264.

2. Владивосток назван третьей модной столицей России. - Текст: электронный // PrimPress: [сайт]. - URL: https://primpress.ru/article/41643 (дата обращения: 21.05.2021). 
3. Волков С. К. Современное состояние туристской сферы Волгоградской области: тенденции развития и точки роста // Научные ведомости. Экономика. Информатика 2019. - Т. 46, №2. - С. 199-204.

4. Гавра Д. П., Таранова Ю. В. Имидж территориальных субъектов в современном информационном пространстве. - Москва: Санкт-Петербург, 2016. - 155 с.

5. Грицак Ю.П. Организация самодеятельного туризма. - Харьков: Экограф, 2019. - 164 с.

6. Можаева Н.Г., Рыбачек Г.В. Организация туристской индустрии и география туризма. - Москва: Форум, 2014. - 336 с.

7. Важенина И. С., Важенин С. Г. Имидж как конкурентный ресурс региона // Регион: экономика и социология. - Новосибирск: Сибирское отделение РАН, 2006. Вып. 4. C. $72-84$.

8. Седых И. А. Индустрия моды. - Текст: электронный // Национальный исследовательский университет «Высшая школа экономики» // Центр развития: [сайт]. - URL: https://dcenter.hse.ru/data/2019/06/03/1495959454/Индустрия\%20моды-2019.pdf (дата обращения: 20.04.2021).

9. Слинкова О. К. Особенности социально-экономического развития на современном этапе: глобальные и региональные тенденции // Научные ведомости Белгородского государственного университета. Серия: История, политология, экономика, Иинформатика. - Белгород: Изд. дом БелГУ, 2011. Вып. 19. - С. 71-75.

10. Ялунер Е. В. Российская индустрия моды: проблемы и перспективы // Известия Санкт-Петербургского государственного экономического университета. - СанктПетербург: Изд-во СПбГЭУ, 2019. Вып. 4. - С. 90-95.

11. Chien Min Chen, Sheu Hua Chen, Hong Tau Lee. Assessing Destination Image Through Combining Tourist Cognitive Perceptions with Destination Resources // International Journal of Hospitality \& Tourism Administration. - 2010. - Vol. 11, № 1. - P. 59-75.

12. Kim S., Park E. First-time and repeat tourist destination image: the case of domestic tourists to Weh Island, Indonesia // An International Journal of Tourism and Hospitality Research. - 2015. - Vol. 26, № 3. - P. 421-433.

13. Poon A. Tourism, technology and competitive strategies // Wallingford: CAB International. - 1993. - № 15. - P. 144-159.

\section{References}

1. Babkin A. V. Special'nye vidy turizma // Voprosy nauki i praktiki: materialy III mezhdunarodnoj nauchno-prakticheskoj konferencii. - 2018. - Razdel 13. Kul'turologiya. S. $262-264$

2. Vladivostok nazvan tret'ej modnoj stolicej Rossii. - Tekst: elektronnyj // PrimPress: [sajt]. URL: https://primpress.ru/article/41643 (data obrashcheniya: 21.05.2021).

3. Volkov S. K. Sovremennoe sostoyanie turistskoj sfery Volgogradskoj oblasti: tendencii razvitiya i tochki rosta // Nauchnye vedomosti. Ekonomika. Informatika - 2019. - T. 46, №2. - S. 199-204.

4. Gavra D.P., Taranova Yu. V. Imidzh territorial'nyh sub"ektov v sovremennom informacionnom prostranstve. - Moskva: Sankt-Peterburg, 2016. - $155 \mathrm{~s}$.

5. Gricak Yu.P. Organizaciya samodeyatel'nogo turizma. - Har'kov: Ekograf, 2019. - $164 \mathrm{~s}$.

6. Mozhaeva N. G., Rybachek G. V. Organizaciya turistskoj industrii i geografiya turizma. Moskva: Forum, 2014. - 336 s.

7. Vazhenina I. S., Vazhenin S. G. Imidzh kak konkurentnyj resurs regiona // Region: ekonomika i sociologiya. - Novosibirsk: Sibirskoe otdelenie RAN, 2006. Vyp. 4. - S. 72-84.

8. Sedyh I. A. Industriya mody. - Tekst: elektronnyj // Nacional'nyj issledovatel'skij universitet «Vysshaya shkola ekonomiki» // Centr razvitiya: [sajt]. - URL: 
https://dcenter.hse.ru/data/2019/06/03/1495959454/Industriya\%20mody-2019.pdf (data obrashcheniya: 20.04.2021).

9. Slinkova O. K. Osobennosti social'no-ekonomicheskogo razvitiya na sovremennom etape: global'nye i regional'nye tendencii // Nauchnye vedomosti Belgorodskogo gosudarstvennogo universiteta. Seriya: Istoriya, politologiya, ekonomika, Iinformatika. - Belgorod: Izd. dom BelGU, 2011. Vyp. 19. - S. 71-75.

10. Yaluner E. V. Rossijskaya industriya mody: problemy i perspektivy // Izvestiya SanktPeterburgskogo gosudarstvennogo ekonomicheskogo universiteta. - Sankt-Peterburg: Izdvo SPbGEU, 2019. Vyp. 4. - S. 90-95.

(ㄱ) Т.В. Метляева, 2021

() И.Е. Перетолчина, 2021

Для цитирования: Метляева Т.В., Перетолчина И. Е. Особенности развития событийных мероприятий в контексте туристской привлекательности территории // Территория новых возможностей. Вестник Владивостокского государственного университета экономики и сервиса. - 2021. - Т. 13, № 3. - С. 166-182.

For citation: Metlyaeva T.V., Peretolchina I.E. Features of the development of events in the context of the tourist attractiveness of the territory, The Territory of New Opportunities. The Herald of Vladivostok State University of Economics and Service, 2021, Vol. 13, № 3, pp. 166-182.

DOI https://doi.org/10.24866/VVSU/2073-3984/2021-3/166-182

Дата поступления: 15.06.2021. 